Buletin Ilmiah Mat. Stat. Dan Terapannya (Bimaster)

Volume 09, No. 4 (2020), hal 549-558.

\title{
PERBANDINGAN KINERJA PETA KENDALI CUMULATIVE SUM DAN PETA KENDALI EXPONENTIALLY WEIGHTED MOVING AVERAGE
}

\author{
Dhea Trinandya Wijayanti, Helmi, Nurfitri Imro'ah
}

\begin{abstract}
INTISARI
Pada umumnya peta kendali yang sering digunakan dalam pengendalian kualitas statistik adalah peta kendali Shewhart. Peta kendali ini bekerja hanya dengan menggunakan informasi yang terkandung dalam titik sampel terakhir dan mengabaikan informasi dari seluruh barisan titik sampel sebelumnya. Hal ini membuat peta kendali Shewhart kurang efektif dalam mendeteksi pergeseran rata-rata yang relatif kecil pada proses produksi. Sebagai alternatif, dikembangkan peta kendali Cumulative Sum (Cusum) dan peta kendali Exponentially Weighted Moving Average (EWMA). Penelitian ini menerapkan peta kendali Cusum dan peta kendali EWMA serta membandingkan kinerjanya dalam mendeteksi pergeseran rata-rata yang relatif kecil pada data produksi. Tahapan pengerjaan dimulai dari melakukan analisis peta kendali Cusum dan peta kendali EWMA dengan menghitung nilai statistik, batas kendali, dan membentuk grafik setiap peta kendali. Selanjutnya, dihitung nilai Average Run Length (ARL) sebagai acuan untuk membandingkan kinerja kedua peta kendali. Berdasarkan hasil penerapannya pada produksi wajan nomor 18 di CV. XYZ, pada peta kendali Cusum tidak terdapat titik-titik yang berada di luar batas kendali. Namun, pada peta kendali EWMA mampu mendeteksi adanya 9 titik yang berada di luar batas kendali sehingga proses produksi tidak terkendali secara statistik. Selain itu berdasarkan perolehan nilai ARL, diketahui nilai ARL peta kendali EWMA menunjukkan hasil yang lebih kecil yaitu sebesar 45,832 dibandingkan dengan nilai ARL peta kendali Cusum yang sebesar 69,108. Dari hasil analisis didapat kesimpulan bahwa peta kendali EWMA lebih efektif daripada peta kendali Cusum dalam mendeteksi adanya pergeseran rata-rata yang relatif kecil pada produksi wajan nomor 18 di CV. XYZ.
\end{abstract}

Kata Kunci: Cusum, EWMA, ARL

\section{PENDAHULUAN}

Pesatnya perkembangan Ilmu Pengetahuan dan Teknologi (IPTEK) telah mempengaruhi persaingan di bidang industri. Adanya persaingan ini mengharuskan setiap pelaku industri untuk selalu menjaga dan meningkatkan kualitas dari produk yang dihasilkan. Hal ini dikarenakan peran penting kualitas dalam perindustrian. Produk dengan kualitas yang baik tentu dapat memberikan keuntungan dan kepuasan baik bagi produsen maupun konsumen. Selain itu produk yang berkualitas baik juga dapat memberikan nilai lebih terhadap produk itu sendiri.

Namun pada kenyataannya, seringkali terjadi ketidakpuasan konsumen terhadap suatu produk karena kualitasnya yang kurang baik. Hal ini bisa terjadi karena adanya kesalahan-kesalahan pada proses produksi yang mengakibatkan penurunan kualitas produk. Berkaitan dengan hal tersebut, diperlukan suatu penanganan proses produksi yang dikenal dengan pengendalian kualitas statistik atau Statistical Process Control (SPC). Pengendalian kualitas statistik dilakukan dengan menerapkan metode-metode statistik untuk memonitor, menganalisis, mengendalikan, mengelola serta memperbaiki proses sehingga dapat menghasilkan hasil produksi yang lebih baik. Ada tujuh alat yang dapat digunakan dalam pengendalian kualitas statistik. Alat yang dimaksud yaitu lembar kendali, diagram pareto, histogram, diagram pencar, diagram konsentrasi cacat, peta kendali, serta diagram sebab dan akibat. Dari tujuh alat ini, peta kendali adalah yang utama digunakan [1].

Peta kendali merupakan teknik berupa pengamatan terhadap grafik dengan tujuan untuk mengetahui ada atau tidaknya produk yang tidak sesuai dengan spesifikasi. Pengamatan dengan grafik ini akan menjadi pedoman produsen untuk memperbaiki dan meningkatkan kualitas produk agar sesuai dengan standar spesifikasi yang ada. Peta kendali yang sering digunakan adalah peta kendali 
Shewhart. Peta kendali ini bekerja hanya dengan menggunakan informasi yang terkandung dalam titik sampel terakhir. Selain itu peta kendali Shewhart juga mengabaikan informasi dari seluruh barisan titik sampel sebelumnya. Hal ini membuat peta kendali Shewhart kurang efektif digunakan untuk mendeteksi adanya pergeseran rata-rata yang relatif kecil $(\leq 1,5 \sigma)$ yang mengindikasikan adanya keadaan tidak terkendali pada proses produksi [1]. Sebagai alternatif dari peta kendali Shewhart, dikembangkanlah peta kendali Cumulative Sum (Cusum) dan peta kendali Exponentially Weighted Moving Average (EWMA). Kedua peta kendali ini dianggap lebih baik digunakan daripada peta kendali Shewhart untuk mendeteksi pergeseran rata-rata yang relatif kecil pada proses produksi.

Peta kendali Cusum pertama kali diperkenalkan oleh Page pada tahun 1954. Peneliti lain seperti Duncan (1974), Lucas (1976), dan Hawkins (1990) menyatakan bahwa peta kendali Cusum lebih efisien digunakan dari peta kendali $\bar{X}$ untuk mendeteksi variasi kecil pada rata-rata. Sementara itu peta kendali EWMA diperkenalkan oleh Robert pada tahun 1959 dengan simulasi nilai Average Run Length (ARL). Peneliti lain, Crowder (1989), Lucas dan Saccucci (1990) menyatakan bahwa peta kendali EWMA sebagai alternatif yang baik untuk mendeteksi perubahan kecil pada rata-rata proses [6]. Pengamatan pada pergeseran rata-rata yang relatif kecil akan menjaga agar proses produksi tetap stabil sehingga dapat menghasilkan produk yang lebih berkualitas. Hal ini tentunya dapat memberikan keuntungan baik bagi produsen maupun konsumen.

Penelitian ini menerapkan peta kendali Cusum dan peta kendali EWMA, serta membandingkan kinerjanya berdasarkan perolehan nilai ARL. Data yang dianalisis adalah data sekunder berupa jumlah produksi wajan nomor 18 di CV. XYZ periode bulan Oktober hingga bulan Desember tahun 2017. Batasan masalah dalam penelitian ini yaitu pendeteksian pergeseran rata-rata proses yang relatif kecil $(\leq 1,5 \sigma)$ pada data produksi. Selain itu, untuk peta kendali Cusum digunakan parameter $k=0,5$ dan $h=5$, sedangkan untuk peta kendali EWMA digunakan parameter $\lambda=0,05$ dan $L=2,615$. Tujuan akhir dari penelitian ini adalah mengetahui peta kendali yang lebih efektif dalam mendeteksi pergeseran rata-rata yang relatif kecil pada proses produksi wajan nomor 18 di CV. XYZ.

\section{PETA KENDALI}

Peta kendali merupakan teknik utama dalam pengendalian kualitas statistik berupa grafik yang menggambarkan karakteristik kualitas yang diukur dari sampel terhadap nomor sampel atau waktu [1]. Peta kendali terdiri dari Garis Tengah (GT) yang merupakan nilai rata-rata dari karakteristik kualitas, serta dua garis lain yang disebut dengan Batas Kendali Atas (BKA) dan Batas Kendali Bawah (BKB). Bentuk dasar grafik peta kendali ditunjukkan seperti pada Gambar 1.

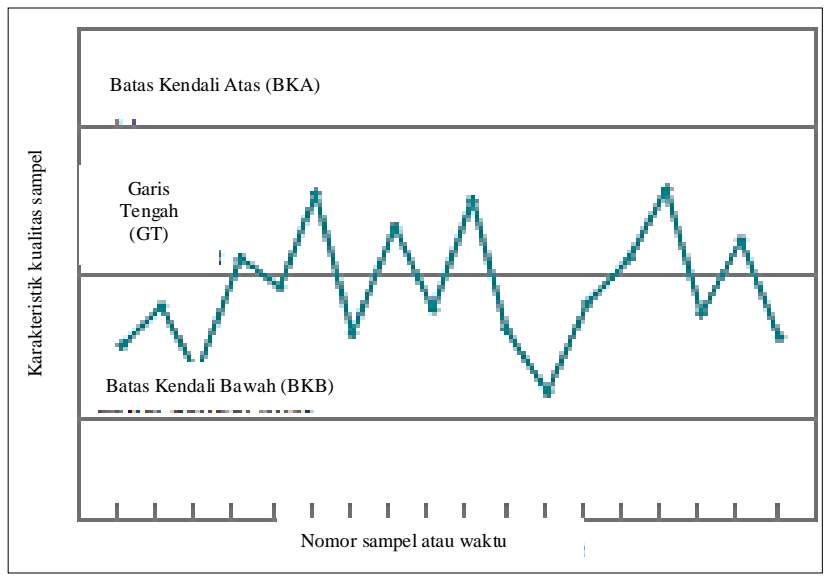

Sumber: Montgomery (2009)

Gambar 1. Grafik Peta Kendali

Apabila suatu proses berada dalam kendali, maka nilai semua sampel akan berada di antara BKA dan BKB seperti pada Gambar 1. Pada kondisi ini tidak diperlukan tindakan perbaikan. Namun sebaliknya 
apabila terdapat nilai sampel yang berada di luar BKA dan BKB, maka proses dikatakan tidak terkendali. Kondisi tidak terkendali ini memerlukan tindakan pemeriksaan dan perbaikan untuk mengetahui sebab dari kondisi tersebut. Secara umum peta kendali dirumuskan dengan [2]:

$$
\begin{aligned}
B K A & =\mu_{w}+p \sigma_{w} \\
G T & =o_{w} \\
B K B & =\mu_{w}-p \sigma_{w}
\end{aligned}
$$

dengan $\mu_{w}$ adalah nilai rata-rata dari sampel $w, \sigma_{w}$ adalah standar deviasi dari sampel $w$, dan $p$ adalah jarak batas dari garis tengah. Teori peta kendali pertama kali diperkenalkan oleh Walter A. Shewhart pada tahun 1924 dan mengalami perkembangan dengan prinsip yang sama yang dikenal dengan peta kendali Shewhart.

Berdasarkan karakteristik kualitasnya, peta kendali Shewhart dapat dibagi menjadi dua jenis yaitu peta kendali variabel dan peta kendali atribut. Peta kendali variabel digunakan jika karakteristik kualitas sampel dapat diukur dan dinyatakan dalam bilangan seperti pengukuran suhu, berat, dan volume. Contoh peta kendali variabel yaitu peta kendali $\bar{X}-R, \bar{X}-\mathrm{S}$, dan $I-M R$. Peta kendali atribut digunakan apabila karakteristik kualitas sampel dinyatakan dalam bentuk sesuai atau tidak sesuai spesifikasi. Contoh peta kendali atribut yaitu peta kendali $p, n p, c$ dan $u$ [2].

\section{AVERAGE RUN LENGTH (ARL)}

Evaluasi kinerja grafik peta kendali dapat dilakukan dengan mengukur seberapa cepat peta kendali tersebut menangkap sinyal tidak terkendali. Salah satu caranya adalah menggunakan nilai ARL. ARL merupakan rata-rata observasi yang harus digambarkan sebelum muncul sinyal tidak terkendali. Pada peta kendali Shewhart, ARL dinyatakan dengan rumus $A R L=\frac{1}{\alpha}$ dimana $\alpha$ adalah probabilitas kesalahan tipe I (menyatakan keadaan tidak terkendali padahal keadaan tersebut terkendali) [1]. Semakin kecil nilai ARL peta kendali maka semakin cepat peta kendali tersebut mendeteksi adanya sinyal tidak terkendali. Grafik peta kendali yang lebih cepat mendeteksi adanya sinyal tidak terkendali dianggap lebih efektif dalam mendeteksi adanya pergeseran rata-rata proses.

\section{PETA KENDALI CUSUM}

Peta kendali Cusum merupakan rangkaian teknik analisis data yang dikembangkan pertama kali di Inggris pada tahun 1954 oleh E. S Page. Peta kendali ini secara langsung menggabungkan informasi dari barisan nilai sampel sebelumnya untuk menjadi titik observasi, dengan cara menampilkan jumlah kumulatif deviasi dari nilai rata-rata sampel atas nilai target. Hal ini menyebabkan peta kendali Cusum menjadi lebih efektif digunakan daripada peta kendali Shewhart untuk mendeteksi pergeseran rata-rata proses yang relatif kecil.

Misalkan $X$ adalah variabel acak dari proses yang berdistribusi normal dengan rata-rata ketika proses terkendali $\mu_{0}$, rata-rata ketika proses tidak terkendali $\mu_{1}$ dengan variansi $\sigma^{2}$ [4]. Jika untuk memonitor rata-rata proses $\mu_{0}$ diambil sampel selama $m$ periode dengan ukuran sampel $n \geq 1$, maka dengan $\bar{x}_{j}$ adalah rata-rata dari sampel ke- $j$, peta kendali Cusum dibentuk dengan rumus [1]:

$$
C_{i}=\sum_{j=1}^{i}\left(\bar{x}_{j}-\mu_{0}\right)
$$

dengan $C_{i}$ merupakan nilai Cusum sampai dengan sampel ke- $i$.

Cusum Tabular merupakan salah satu cara penyajian untuk peta kendali Cusum. Cusum Tabular bekerja dengan cara mengakumulasikan deviasi dari $\mu_{0}$ yang berada di atas nilai target dengan statistik $\mathrm{C}^{+}$dan mengakumulasikan deviasi dari $\mu_{0}$ yang berada di bawah target dengan statistik $\mathrm{C}^{-}$. Statistik $\mathrm{C}^{+}$dan $\mathrm{C}^{-}$dikenal sebagai Cusum atas satu sisi dan Cusum bawah satu sisi. Jika diketahui nilai $C_{0}^{+}$ dan $C_{0}^{-}$adalah nol, maka untuk $C_{i}^{+}$dan $C_{i}^{-}$dapat dirumuskan sebagai berikut [5]:

$$
C_{i}^{+}=\max \left[0, x_{i}-\left(\mu_{0}+K\right)+C_{i-1}^{+}\right]
$$




$$
\bar{c}_{i}^{-}=\max \left[0,\left(\mu_{0}-K\right)-x_{i}+\bar{c}_{i-1}^{-}\right]
$$

dimana $\mu_{0}$ adalah nilai target, dan $x_{i}$ adalah nilai sampel dengan $i=1,2,3, \ldots, m$. Penyusunan grafik peta kendali Cusum Tabular perlu menggunakan parameter $H$ dan $K . K$ merupakan nilai referensi (slack value) dan $H$ merupakan interval keputusan atau batas kendali. Nilai $K$ dan $H$ ditentukan dengan rumus:

$$
\begin{aligned}
& K-k \sigma \\
& H=h r
\end{aligned}
$$

dengan $\sigma$ adalah standar deviasi dari proses. Apabila nilai $C_{i}{ }^{+}$atau $C_{i}^{-}$melebihi nilai batas kendali $H$, maka proses berada di luar kendali.

Berdasarkan studi analisis terkait kinerja ARL peta kendali Cusum, direkomendasikan untuk menggunkan parameter $k=\frac{1}{2}$ dan parameter $h=4$ atau $h=5$. Penggunaan parameter dengan nilai tersebut akan memberikan kinerja yang baik untuk peta kendali Cusum. Hal ini didasarkan dari perolehan ARLnya pada pergeseran rata-rata io [5]. Diberikan Tabel 1 yang menunjukkan kinerja ARL peta kendali Cusum.

Tabel 1. ARL Peta Kendali Cusum

\begin{tabular}{rrrr}
\hline Shift in Mean (Multiple of $\sigma)$ & \multicolumn{2}{c}{$h=4$} & \multicolumn{2}{c}{$h=5$} \\
\hline 0,00 & 168,00 & 465,00 \\
0,25 & 74,20 & 139,00 \\
0,50 & 26,60 & 38,00 \\
0,75 & 13,30 & 17,00 \\
1,00 & 8,38 & 10,40 \\
1,50 & 4,75 & 5,75 \\
2,00 & 3,34 & 4,01 \\
2,50 & 2,62 & 3,11 \\
3,00 & 2,19 & 2,57 \\
4,00 & 1,71 & 2,01 \\
\hline
\end{tabular}

Sumber: Montgomery (2009)

Jika $\Delta \mu$ adalah deviasi perubahan nilai rata-rata akibat pergeseran atas nilai target, dengan standar deviasi $\sigma$, maka besar pergeseran rata-rata proses dalam unit standar deviasi dapat dihitung dengan rumus [1]:

$$
\delta=\frac{\Delta \mu}{\sigma} \text {, dengan } \sigma \neq 0
$$

\section{PETA KENDALI EWMA}

Peta kendali EWMA pertama kali diperkenalkan oleh Robert pada tahun 1959. Cara kerja peta kendali EWMA sama seperti pada peta kendali Cusum namun lebih mudah dioperasikan daripada peta kendali Cusum [6]. Peta kendali EWMA bekerja dengan tidak hanya mempertimbangkan sampel terakhir sebagai titik yang diamati, tetapi juga menggabungkan informasi dalam barisan nilai sampel sebelumnya untuk memperoleh titik plot yang nantinya akan diamati pada grafik. Peta kendali EWMA dapat digunakan pada sampel individual maupun subgrup dengan ukuran sampel $n>1$.

Jika diasumsikan observasi dari proses dengan variabel $X \sim N\left(\mu, \sigma^{2}\right)$, maka peta kendali EWMA dapat didefinisikan sebagai berikut [1]:

dengan:

$$
Z_{i}=\lambda x_{i}+(1-\lambda) Z_{i=1}
$$

$Z_{i}-$ nilai EWMA dengan $i-1,2,3, \ldots, m$

$x_{i}=$ sampel dengan $i=1,2,3, \ldots, m$

$\lambda=$ parameter bobot yang bernilai $0 \leq \lambda \leq 1$ 
Nilai awal EWMA yaitu $Z_{0}$ dapat diperoleh dari nilai rata-rata target yang ditetapkan produsen, sehingga $Z_{0}=\mu_{0}$ atau dengan rata-rata proses yang diamati, sehingga menjadi $Z_{0}=\bar{x}$.

Batas-batas peta kendali EWMA dapat dirumuskan sebagai berikut:

$$
\begin{aligned}
B K A & =\mu_{0}+L \sigma \sqrt{\frac{\lambda(1-(1-\lambda)}{2-\lambda}} \\
G T & =\mu_{0} \\
B K B & =\mu_{0}-L \sigma \sqrt{\frac{\lambda(1-(1-\lambda))^{2}}{2-\lambda}}
\end{aligned}
$$

dimana $L$ menyatakan lebar batas kendali dan $\sigma$ adalah standar deviasi.

Beberapa penelitian dilakukan terkait kinerja ARL peta kendali EWMA. Salah satunya adalah penelitian dari Lucas dan Saccucci yang melakukan simulasi nilai ARL dengan komputasi program C. Berdasarkan hasil simulasi, disimpulkan bahwa peta kendali EWMA akan berkinerja dengan baik jika menggunakan parameter $\lambda=0,40$ dengan $L=3,054, \lambda=0,25$ dengan $L=2,998, \lambda=0,20$ dengan $L=2,962, \lambda=0,10$ dengan $L=2,814$, dan $\lambda=0,05$ dengan $L=2,615$. Tabel 2 merupakan tabel yang menunjukkan perolehan nilai ARL peta kendali EWMA untuk parameter yang direkomendasikan Lucas dan Saccucci [6].

Tabel 2. Kinerja ARL Peta Kendali EWMA

\begin{tabular}{rrrrrr}
\hline $\begin{array}{c}\text { Shift in Mean } \\
\text { (Multiple of } \sigma)\end{array}$ & $\begin{array}{r}L=3,054 \\
\lambda=0,40\end{array}$ & $\begin{array}{c}L=2,998 \\
\lambda=0,25\end{array}$ & $\begin{array}{c}L=2,962 \\
\lambda=0,20\end{array}$ & $\begin{array}{c}L=2,814 \\
\lambda=0,10\end{array}$ & $\begin{array}{c}c \\
\lambda=2,615 \\
\lambda=0,05\end{array}$ \\
\hline 0,00 & 500,00 & 500,00 & 500,00 & 500,00 & 500,00 \\
0,25 & 224,00 & 170,00 & 150,00 & 106,00 & 84,10 \\
0,50 & 71,20 & 48,20 & 41,80 & 31,30 & 28,80 \\
0,75 & 28,40 & 20,10 & 18,20 & 15,90 & 16,40 \\
1,00 & 14,30 & 11,10 & 10,50 & 10,30 & 11,40 \\
1,50 & 5,90 & 5,50 & 5,50 & 6,10 & 7,10 \\
2,00 & 3,50 & 3,60 & 3,70 & 4,40 & 5,20 \\
2,50 & 2,50 & 2,70 & 2,90 & 3,40 & 4,20 \\
3,00 & 2,00 & 2,30 & 2,40 & 2,90 & 3,50 \\
4,00 & 1,40 & 1,70 & 1,9 & 2,20 & 2,70 \\
\hline
\end{tabular}

Sumber: Kalgoda, Khosti, dan Ashokan (2011)

\section{HASIL DAN PEMBAHASAN}

Data yang digunakan adalah data produksi wajan nomor 18 di CV. XYZ periode bulan Oktober hingga bulan Desember tahun 2017. Data yang diambil merupakan data sekunder dari sebuah penelitian yang meneliti tentang implementasi metode Lean Six Sigma pada produksi wajan nomor 18 di CV. XYZ. Secara umum statistik deskriptif untuk data yang digunakan dalam penelitian ini dapat

\begin{tabular}{|c|c|c|c|c|c|}
\hline Mean & $\begin{array}{l}\text { Standar } \\
\text { Deviasi }\end{array}$ & Minimum & Maksimum & Jumlah & $\mathrm{N}$ \\
\hline 112,13 & 5,939 & 103 & 128 & 4.373 & 39 \\
\hline
\end{tabular}
dilihat pada Tabel 3.

Tabel 3. Statistik Deskriptif

Diketahui bahwa sebanyak 39 sampel digunakan dalam penelitian ini. Jumlah keseluruhan untuk produksi wajan nomor 18 selama bulan Oktober hingga bulan Desember tahun 2017 adalah 4.373 unit dengan rata-rata produksi 112 unit. Produksi paling terbanyak wajan nomor 18 adalah 128 unit yang diproduksi pada tanggal 3 November 2017, sedangkan produksi paling sedikit terjadi pada tanggal 16 Oktober 2017 yang hanya sebanyak 103 unit. Standar deviasi yang diperoleh adalah 5,939 unit yang menggambarkan keragaman dari data jumlah produksi wajan nomor 18 di CV. XYZ. 
Sebelum dilakukan analisis peta kendali Cusum dan peta kendali EWMA, terlebih dahulu dilakukan pengujian normalitas pada data jumlah produksi wajan nomor 18. Pengujian dilakukan dengan uji Kolmogorov-Smirnov dengan hasil sebagai berikut:

Tabel 4. Hasil Uji Normalitas

\begin{tabular}{lc}
\hline \multicolumn{2}{c}{ Jumlah Produksi Wajan Nomor 18} \\
\hline$D_{\text {matung }}$ & 0,101 \\
$D_{\text {zabel }}$ & 0,216 \\
\hline
\end{tabular}

Berdasarkan Tabel 4 diketahui bahwa nilai $D_{\text {hitamg }}<D_{\text {tabel }}$, sehingga $H_{0}$ diterima yang berarti data jumlah produksi wajan nomor 18 memenuhi asumsi berdistribusi normal. Karena data produksi memenuhi asumsi ditribusi normal, maka data produksi dapat dianalisis lebih lanjut dengan peta kendali Cusum dan peta kendali EWMA.

Analisis peta kendali Cusum yang dilakukan adalah dengan penyajian Cusum Tabular. Analisis diawali dengan menghitung nilai $K$ dan $\|$ menggunakan Persamaan (3) dan Persamaan (4). Jika pada penelitian ini digunakan parameter $k=0,5$ dan $h=5$, maka dengan $\sigma=5,939$ diperoleh:

$$
\begin{aligned}
& K=0,5(5,939)=2,9695 \\
& H=5(5,939)=29,695
\end{aligned}
$$

Sehingga diperoleh nilai $K$ sebesar 2,9695. Nilai ini nantinya akan digunakan pada perhitungan nilai $C_{i}^{+}$dan $C_{i}^{-}$. Nilai $H$ yang diperoleh sebesar 29,695 akan menjadi batas kendali, $H^{+}$sebagai BKA dan $\mathrm{H}^{-}$sebagai BKB pada peta kendali Cusum Tabular.

Selanjutnya ditetapkan nilai target proses berdasarkan nilai rata-rata produksi wajan nomor 18 pada periode sebelumnya yang sebesar 114,64 , sehingga diperoleh $\mu_{0}=114,64$. Setelah diperoleh nilai $\mu_{\mathbb{g}}$, dihitung $C_{i}^{+}$untuk $i=1$ dengan $C_{0}^{+}=0$ menggunakan Persamaan (1) sebagai berikut.

$$
\begin{aligned}
{C_{1}}^{+} & =\max [0,118-(114,64+2,9695)+0] \\
& =\max [0,0,391] \\
& =0,391
\end{aligned}
$$

Didapatlah nilai $\boldsymbol{C}_{1}^{+}$sebesar 0,391 . Nilai ini kemudian digunakan untuk memperoleh nilai $C_{2}^{+}$. Langkah perhitungan yang sama dilakukan hingga diperoleh nilai $C_{39}^{+}$. Kemudian dihitung juga $C_{i}^{-}$ untuk sampel $i=1$ dengan diketahui $C_{0}^{-}=0$ menggunakan Persamaan (2).

$$
\begin{aligned}
{C_{1}^{-}}^{-} & =\max [0,(114,64-2,9695)-118+0] \\
& =\max [0,-6,330] \\
& =0
\end{aligned}
$$

Langkah perhitungan yang sama juga dilakukan sehingga diperoleh nilai $C_{2}^{-}$hingga $C_{39}^{-}$. Setelah semua nilai diperoleh, dibentuk grafik peta kendali Cusum Tabular seperti pada Gambar 2.

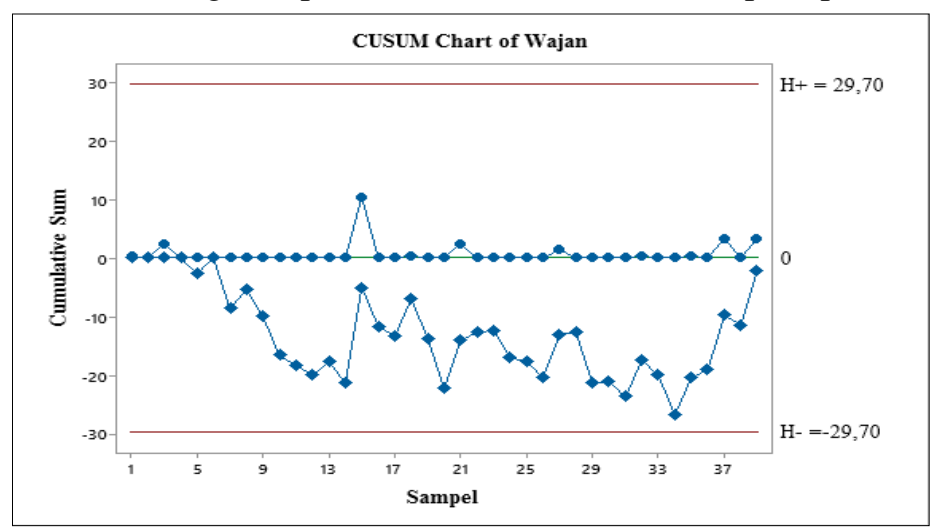

Gambar 2. Grafik Peta Kendali Cusum Tabular 
Berdasarkan Gambar 2 dapat dilihat bahwa terdapat dua garis plot yang merupakan garis plot dari nilai-nilai statistik $C_{i}{ }^{+}$dan $C_{i}^{-}$. Selain itu, terdapat dua garis lurus horizontal berupa nilai parameter $H$ yang menjadi BKA dan BKB pada peta kendali Cusum Tabular. Diketahui bahwa titik-titik nilai $C_{i}^{+}$

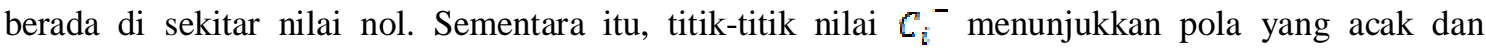
cenderung menurun dengan terdapat satu titik yang mendekati nilai batas kendali $H$, yaitu pada titik $\mathrm{C}_{34}{ }^{-}$. Meskipun demikian, semua titik-titik nilai ${\mathrm{C}_{i}}^{+}$dan $\mathrm{C}_{i}^{-}$masih berada dalam batas kendali $H$, sehingga dapat dikatakan bahwa proses produksi wajan nomor 18 terkendali secara statistik. Kondisi ini berarti proses produksi wajan nomor 18 masih sesuai dengan target produksi sehingga tidak memerlukan tindakan perbaikan.

Langkah selanjutnya adalah analisis peta kendali EWMA. Analisis dilakukan dengan menggunakan parameter $\lambda=0,05, L=2,615$, dan nilai target sebagai nilai awal EWMA, sehingga $Z_{0}=114,64$. Berikut ini diberikan perhitungan $Z_{i}$ untuk sampel $i=1$ menggunakan Persamaan (6):

$$
\begin{aligned}
Z_{1} & =(0,05)(118)+(1-0,05)(114,64) \\
& =(5,9)+(0,95)(114,64) \\
& =(5,9)+(108,908) \\
& =114,8080
\end{aligned}
$$

Didapatlah nilai untuk $Z_{1}$ sebesar 114,8080 yang kemudian digunakan untuk memperoleh nilai $Z_{2}$. Langkah perhitungan yang sama dilakukan hingga diperoleh nilai $Z_{39}$. Selanjutnya untuk sampel yang sama, dihitung BKA dengan Persamaan (7) sebagai berikut:

$$
\begin{aligned}
B K A & =114,64+(2,615)(5,939) \sqrt{\frac{(0,05)(1-(1-0,05)(11)}{(2-0,05)}} \\
& =114,64+(15,5305)(\sqrt{0,0025}) \\
& =114,64+(15,5305)(0,05) \\
& =115,4165
\end{aligned}
$$

Berdasarkan Persamaan (8), diperoleh nilai GT $=114,64$. Kemudian BKB untuk $i=1$ yang dihitung menggunakan Persamaan (9) diperoleh sebesar:

$$
\begin{aligned}
B K B & =114,64-(2,615)(5,939) \sqrt{\frac{(0.05)\left(1-(1-0.05)^{2(12)}\right.}{(2-0.05)}} \\
& =114,64-(15,5305)(\sqrt{0,0025}) \\
& =114,64-(15,5305)(0,05) \\
& =113,6635
\end{aligned}
$$

Perhitungan dengan rumus yang sama dilakukan untuk memperoleh nilai BKA dan BKB sampai sampel $i=39$. Jika semua nilai sudah diperoleh, dibentuk grafik peta kendali EWMA seperti pada Gambar 3.

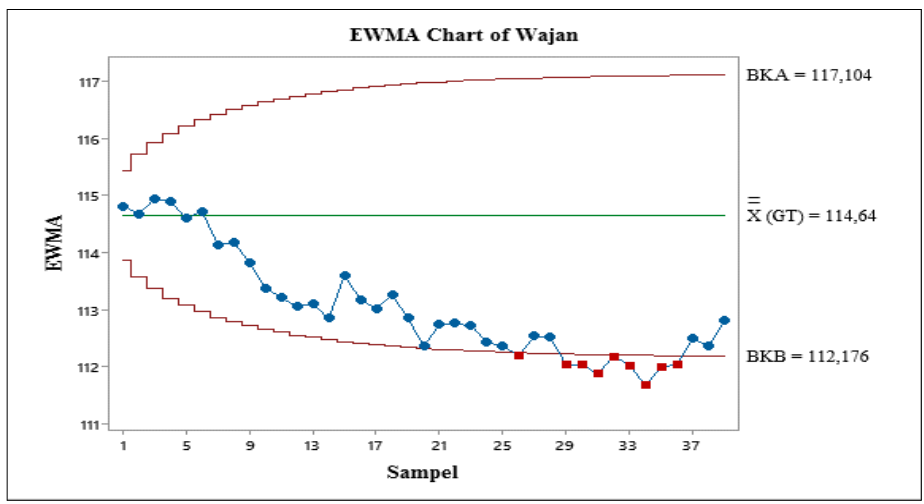

Gambar 3. Grafik Peta Kendali EWMA 
Diketahui bahwa titik-titik nilai $Z_{i}$ membentuk pola yang cenderung menurun. Selain itu, terdapat 9 titik yang berada di bawah nilai BKB, yaitu titik ke-26, ke-29, 30, 31, 32, 33, 34, 35, dan 36. Hal ini mengakibatkan proses produksi wajan nomor 18 tidak terkendali secara statistik. Titik-titik yang berada di luar batas kendali ini menunjukkan bahwa telah terjadi penyebab-penyebab terduga yang membuat proses produksi wajan nomor 18 tidak sesuai dengan target produksi. Penyebab-penyebab terduga ini bisa disebabkan dari faktor bahan baku yang kurang baik kualitasnya, faktor mesin dan metode kerja yang tidak sesuai dengan standar operasional pengerjaan, dan faktor pekerja yang kurang terampil, tidak profesional, lalai, ataupun kelelahan. Selain itu, fakor lingkungan juga dapat mempengaruhi pekerja ataupun produk wajan itu sendiri. Terkait hal ini, perusahaan dapat melakukan analisis lebih lanjut sehingga dapat segera dilakukan perbaikan untuk proses produksi ke depannya.

Setelah dilakukan analisis peta kendali Cusum dan peta kendali EWMA, analisis dilanjutkan dengan melakukan perhitungan nilai ARL untuk kedua peta kendali. Jika diketahui rata-rata produksi wajan nomor 18 adalah $\mu_{1}=112,13$ dan nilai rata-rata targetnya $\mu_{0}=114,64$, maka dengan $\sigma=5,939$ besar pergeseran yang diperoleh dengan Persamaan (5) adalah:

$$
\delta=\frac{\Delta \mu}{\pi}=\frac{(112,13-114,64)}{\text { F.9.9 }}=-0,423
$$

Nilai $-0,423$ menunjukkan bahwa rata-rata proses mengalami pergeseran ke bawah (penurunan) sebesar 0,423. Langkah selanjutnya adalah menghitung nilai ARL berdasarkan besar pergeseran ratarata proses yang diperoleh. Pada penelitian ini perhitungan ARL dilakukan dengan mengacu pada Tabel 1 untuk peta kendali Cusum dan Tabel 2 untuk peta kendali EWMA.

Dapat diketahui dari kedua tabel bahwa tidak terdapat nilai ARL untuk besar pergeseran $\delta=0,423$. Oleh karena itu, untuk mendapatkan nilai ARLnya dilakukan pendekatan nilai menggunakan rumus interpolasi berikut:

$$
A=A_{0}+\frac{\left(A_{1}-A_{0}\right)}{\left(B_{1}-B_{0}\right)}\left(B-B_{0}\right)
$$

dengan:

$A=$ nilai ARL yang dicari

$A_{0}=$ nilai ARL awal yang diketahui

$A_{1}=$ nilai ARL akhir yang diketahui

$B=$ nilai pergeseran yang dicari

$B_{0}=$ nilai pergeseran awal yang diketahui

$B_{1}=$ nilai pergeseran akhir yang diketahui

Berdasarkan Tabel 1 diketahui bahwa besar pergeseran $B=0,423$ terletak di antara $B_{0}=0,25$ dan $B_{1}=0,5$. Jika diketahui nilai ARL untuk $B_{0}$ adalah $A_{0}=139$ dan untuk $B_{1}$ adalah $A_{1}=38,0$, maka nilai ARL untuk besar pergeseran $B=0,423$ :

$$
\begin{aligned}
A & =139+\frac{(38-139)}{(0,5-0,25)}(0,423-0,25) \\
& =139+(-69,892) \\
& =69,108
\end{aligned}
$$

Diperoleh nilai ARL sebesar 69,108, yang berarti peta kendali Cusum dapat mendeteksi adanya keadaan tidak terkendali pertama rata-rata pada titik ke-69,108.

Selanjutnya untuk peta kendali EWMA dihitung nilai ARL berdasarkan Tabel 2. Diketahui bahwa besar pergeseran $\bar{D}-0,423$ terletak di antara $B_{0}=0,25$ dan $D_{1}-0,5$. Jika nilai ARL untuk $B_{0}$ adalah $A_{0}-04,1$ dan untuk $B_{1}$ adalah $A_{1}=28,8$, maka ARL untuk $B=0,223$ adalah:

$$
\begin{aligned}
A & =84,1+\frac{(28,8-84,1)}{(0,5-0,25)}(0,423-0,25) \\
& =84,1+(-38,2676) \\
& =45,832
\end{aligned}
$$


Diperoleh nilai ARL untuk peta kendali EWMA sebesar 45,832. Nilai ini berarti peta kendali EWMA dapat mendeteksi adanya keadaan tidak terkendali pertama rata-rata pada titik ke- 45,832 .

Berdasarkan perolehan nilai ARL kedua peta kendali dapat disimpulkan bahwa peta kendali EWMA lebih efektif dalam mendeteksi adanya keadaan tidak terkendali dibandingkan peta kendali Cusum. Nilai ARL peta kendali EWMA menunjukkan hasil yang lebih kecil yaitu sebesar 45,832 daripada nilai ARL peta kendali Cusum yang sebesar 69,108. Perolehan nilai ARL yang lebih kecil ini mengindikasikan bahwa peta kendali EWMA lebih sensitif daripada peta kendali Cusum. Artinya peta kendali EWMA lebih cepat mendeteksi adanya pergeseran rata-rata yang relatif kecil pada proses produksi wajan nomor 18 di CV. XYZ.

\section{KESIMPULAN}

Berdasarkan analisis peta kendali Cusum dengan parameter $k=0,5$ dan $h=5$, diketahui bahwa proses produksi wajan nomor 18 di CV. XYZ sudah terkendali secara statistik. Grafik peta kendali Cusum menunjukkan tidak terdapat titik-titik yang berada di luar batas kendali. Namun, berdasarkan analisis peta kendali EWMA dengan parameter $\lambda=0,05$ dan $L=2,615$, proses produksi wajan nomor 18 di CV. XYZ tidak terkendali secara statistik. Hal ini karena adanya 9 titik yang berada di bawah nilai BKB, yaitu pada titik ke-26, titik ke-29, 30, 31, 32, 33, 34, 35, dan 36. Adanya titik-titik yang berada di luar batas kendali ini menunjukkan bahwa telah terjadi penyebab-penyebab terduga yang membuat produksi wajan nomor 18 tidak terkendali. Penyebab-penyebab terduga ini bisa disebabkan dari faktor bahan baku, faktor mesin dan metode kerja, faktor pekerja, serta faktor lingkungan yang dapat mempengaruhi pekerja ataupun produk wajan itu sendiri.

Selain itu, berdasarkan perolehan nilai ARL diketahui bahwa peta kendali EWMA lebih efektif dalam mendeteksi adanya keadaan tidak terkendali dibandingkan peta kendali Cusum. Nilai ARL peta kendali EWMA menunjukkan hasil yang lebih kecil yaitu sebesar 45,832 daripada nilai ARL peta kendali Cusum yang sebesar 69,108. Perolehan nilai ARL yang lebih kecil ini mengindikasikan bahwa peta kendali EWMA lebih sensitif daripada peta kendali Cusum. Artinya peta kendali EWMA lebih cepat mendeteksi adanya pergeseran rata-rata yang relatif kecil pada proses produksi wajan nomor 18 di CV. XYZ.

\section{DAFTAR PUSTAKA}

[1].Montgomery, D. C. Introduction to Statistical Quality Control. Ed ke-4. New York: John Wiley \& Sons; 2009.

[2].Syukron, A. dan Kholil, M. Six Sigma: Quality for Business Improvement. Ed ke-1. Yogyakarta: Graha Ilmu; 2013.

[3].Rasyidin, M. T., Nohe, D. A. dan Wahyuningsih, S. Statistical Process Control dengan Metode Cumulative Sum (CUSUM) (Studi Kasus Pengendalian Kualitas Rata-Rata Kandungan Produk Susu di Koperasi Peternakan Selatan (KPBS) Bulan April 2012). Jurnal Eksponensial. 2012; 3(2):81-84.

[4].Qadifa, S. S., Mutaqin, A. K. dan Yanti, T. S. Diagram Kendali Rata-Rata Cumulative Sum Nonparametrik. Prosiding Statistika. 2016; 2(2):164-173.

[5].Khosti V. V. Cumulative Sum. International Journal of Physics and Mathematic Sciences. 2011; 1:28-32.

[6].Kalgoda A. A., Khosti V. V. dan Ashokan K. V. Exponentially Weighted Moving Average Control Chart. Asian Journal of Management Research. 2011; 2(1):253-263.

DHEA TRINANDYA WIJAYANTI: Jurusan Matematika FMIPA UNTAN, Pontianak dheaatriw@gmail.com 
HELMI

NURFITRI IMRO'AH
: Jurusan Matematika FMIPA UNTAN, Pontianak helmi@math.untan.ac.id : Jurusan Matematika FMIPA UNTAN, Pontianak nurfitriimroah@math.student.untan.ac.id 